\title{
Pneumatic Distension of Ventricular Mural Architecture Validated Histologically
}

\section{Der pneumatisch gedehnte Herzmuskel im Computer- tomogramm und im histologischen Bild}

Authors

Affiliations
M. C. Burg ${ }^{1}$, P. Lunkenheimer ${ }^{2}$, P. Niederer ${ }^{3}$, C. Brune ${ }^{4}$, K. Redmann ${ }^{5}$, M. Smerup ${ }^{6}$, U. Spiegel ${ }^{7}$, F. Becker ${ }^{7}$, D. Maintz ${ }^{1,8}$, W. Heindel ${ }^{1}$, R. H. Anderson ${ }^{9}$

Affiliation addresses are listed at the end of the article.

\section{Key words}

Q heart CT

- myocardium

- ventricular stucture

- myocardial function

- heart anatomy \& histology

- animal models received 24.6.2015

accepted 11.8.2016

\section{Bibliography}

Dol http://dx.doi.org/ 10.1055/s-0042-115569

Published online: 2016

Fortschr Röntgenstr 2016; 188: 1045-1053 @ Georg Thieme

Verlag KG Stuttgart · New York . ISSN 1438-9029

\section{Correspondence}

Dr. Matthias Christian Burg Department of Clinical

Radiology,

University Hospital Münster

Albert-Schweitzer-Campus 1

48149 Münster

Germany

Tel.: ++ 49/251/8347310

Fax: ++49/251/8349656

matthias@burgsoft.de

\section{Zusammenfassung \\ $\nabla$}

Ziel: Um den Aufbau der linksventrikulären Kammerwände radiologisch zu analysieren, haben wir sie pneumatisch über die Koronararterien gedehnt, sodass Spalträume zwischen den Myokardblöcken entstehen. Das in der Computertomografie dargestellte Muster wurde anschließend histologisch validiert.

Material und Methoden: 10 Schweineherzen wurden gebläht, nachdem 4 durch Infusion kardioplegischer Lösung in Diastole fixiert und 4 durch Bariumchlorid in Systole stillgestellt worden waren. Der lamelläre Aufbau der Wände wurde computertomografisch dargestellt. Die Helixdrehung langer Myozytenketten wurde bestimmt. 2 weitere Herzen wurden histologisch aufgearbeitet.

Ergebnisse: Steigende Blähdrücke führten zu einer Verlängerung der Wände ohne signifikante Zunahme der Wanddicke. Nach Blähung des Interstitiums zwischen den lamellären Myokardblöcken trennen sich optisch eine subepikardiale, eine zentrale und eine subendokardiale Region durch ihre unterschiedlich angeordnete Fiederung. Über die Kammerwände herrscht eine ausgeprägte Variation der Dicke dieser Regionen. Es bestehen keine bindegewebigen Grenzen zwischen ihnen. Die Muskelblöcke weichen unterschiedlich stark von einer oberflächenparallelen Anordnung ab. Beim Scrollen durch den Myokardkörper von der Basis zum Apex stellt sich eine spiralige Vernetzung der Myokardblöcke dar. Schlussfolgerung: Nach interstitieller Blähung bestätigt sich für die Struktur des Herzmuskels nicht die Annahme seiner einheitlichen tangentialen Anordnung. Es besteht regional eine ausgeprägte $\mathrm{He}$ terogenität. Lamelläre Aggregate erstrecken sich niemals vollständig transmural. Ihre nicht allein tangentiale Anordnung legt das Vorherrschen eines antagonistischen Wechselspieles von entlastenden und auxotonen Kräften nahe.

\section{Abstract \\ $\nabla$}

Purpose: There are ongoing arguments as to how cardiomyocytes are aggregated together within the ventricular walls. We used pneumatic distension through the coronary arteries to exaggerate the gaps between the aggregated cardiomyocytes, analyzing the pattern revealed using computed tomography, and validating our findings by histology.

Methods: We distended 10 porcine hearts, arresting 4 in diastole by infusion of cardioplegic solutions, and 4 in systole by injection of barium chloride. Mural architecture was revealed by computed tomography, measuring also the angulations of the long chains of cardiomyocytes. We prepared the remaining 2 hearts for histology by perfusion with formaldehyde.

Results: Increasing pressures of pneumatic distension elongated the ventricular walls, but produced insignificant changes in mural thickness. The distension exaggerated the spaces between the aggregated cardiomyocytes, compartmenting the walls into epicardial, central, and endocardial regions, with a feathered arrangement of transitions between them. Marked variation was noted in the thicknesses of the parts in the different ventricular segments, with no visible anatomical boundaries between them. Measurements of angulations revealed intruding and extruding populations of cardiomyocytes that deviated from a surface-parallel alignment. Scrolling through the stacks of tomographic images revealed marked spiraling of the aggregated cardiomyocytes when traced from base to apex.

Conclusion: Our findings call into question the current assumption that cardiomyocytes are uniformly aggregated together in a tangential fashion. There is marked heterogeneity in the architecture of the different ventricular segments, with the aggregated units never extending in a fully transmural fashion. 


\section{Kernaussaugen:}

- Die Computertomografie des pneumatisch gedehnten Myokards zeigt eine organisierte Struktur der Ventrikelwände.

> Kardiomyozyten sind zu einem hoch strukturierten Kontinuum mit ausgeprägter regionaler Heterogenität verknüpft.

- Die globale Herzfunktion ist das Ergebnis der Kräfte von Blöcken aggregierter Kardiomyozyten.
Key Points:

> Pneumographic computed tomography reveals an organized structure of the ventricular walls.

- Aggregated cardiomyocytes form a structured continuum, with marked regional heterogeneity.

$>$ Global ventricular function results from antagonistic forces generated by aggregated cardiomyocytes.

Citation Format:

> Burg MC, Lunkenheimer P, Niederer P et al. Pneumatic Distension of Ventricular Mural Architecture Validated Histologically. Fortschr Röntgenstr 2016; 188: 1045-1053

\section{Introduction}

$\nabla$

It is perhaps surprising that after four centuries of investigation [1] there is still no consensus as to how cardiomyocytes are aggregated together within the ventricular walls. As well as demonstrating their clinical utility [2], computed tomography and magnetic resonance imaging have proven valuable in the experimental setting for imaging the ventricular mural architecture. Diffusion tensor magnetic resonance imaging, for example, is able to reveal the tracks formed by the long chains of cardiomyocytes [3 - 5]. Previous histological studies had shown marked changes in so-called helical angulation when the chains of cardiomyocytes were traced through the depths of the ventricular walls [6]. It has been assumed, however, that the cardiomyocytes themselves are aggregated together to form so-called "sheets", with the alleged sheets, as viewed relative to the long axis of the ventricular cone, shown as extending in full transmural fashion, and said to uniformly contain four to six cardiomyocytes in their thickness [7]. These assumptions are in conflict with older histological studies of Feneis [8] and Hort [9]. These investigators showed that, when assessed in the short axis of the ventricular cone, an obvious feathered pattern could be seen in the ventricular walls. The widely held notion that all cardiomyocytes are aligned in tangential fashion within the cone, as proposed by Frank [10], is incompatible with studies revealing populations of cardiomyocytes that intrude or extrude in a transmural fashion [11-13]. Despite these potential disagreements, there is little doubt that the cardiomyocytes are aggregated together to form units separated by planes of cleavage. This is the consequence of the packing together of the individual cardiomyocytes within the endomysial component of the fibrous matrix to form the units, with looser perimysial tissues occupying the spaces between the aggregated cardiomyocytes [14]. In an earlier study, these spaces between the units were exaggerated by pneumatic distension, thus providing better evidence of the extent and alignment of the myocardial components formed from the aggregated cardiomyocytes [15]. In this current study, we carried out further analysis of the angulation of the aggregated units of the myocardium visualized subsequent to pneumatic distension, which reveals the marked regional heterogeneity of the mural architecture within the ventricular cone. Our findings call into question whether the long chains of cardiomyocytes are aggregated together to form sheets that extend in a fully transmural fashion.

\section{Materials and methods}

\section{$\nabla$}

We pneumatically distended 10 excised porcine hearts, following all procedures for animal care and experimentation as summarized in the guidelines of the American Physiological Society and the Ger- man Law of Animal Protection. Our protocols were approved by the University of Muenster Institutional Animal Care and Use Committee and adhered to the guidelines for the use of laboratory animals of the National Institutes of Health and Prevention.

All hearts were excised at the end of the experiments of different nature, with the procedures themselves in some instances lasting for several hours. The pigs remained under general anesthesia while the hearts were quickly excised, excision beginning when the main investigator had indicated that the primary experiment was finalized. In four instances, after the excision, cannulas were inserted into the right coronary, circumflex, and anterior interventricular arteries while the hearts were still beating. The arteries were then perfused with crystalline cardioplegic solution (Custodiol, Köhler Chemie) until contractile activity had ceased, thus inducing arrest in a state of diastole. In an additional 4 hearts, we perfused the cannulated coronary arteries with barium chloride, thus inducing systolic cardiac arrest. We excised a further 2 hearts for histological examination. In all instances, having excised the hearts, we inflated the coronary arteries with compressed air. For this purpose, cannulas were sewn into the coronary arteries to produce an airtight seal. The pressure of perfusion was measured using a manometer at the entrance of the tubing through which we delivered compressed air. The hearts arrested in either systole or diastole were then imaged using computed tomography, first in the control state, and then while the coronary arteries were gently inflated by delivering compressed air at rising pressures of 100, 150, 200 and 300 kilopascals. The insufflation of air continued throughout the period of computed tomographic interrogation. For computed tomographic imaging, we used a dual-source system (Somatom Definition, Siemens Healthcare, Forchheim, Germany) with the following scan parameters: $120 \mathrm{kV}, 100 \mathrm{mAs}$, collimation $16 \times 0.3 \mathrm{~mm}$, matrix $512 \times 512$, FOV $12 \mathrm{~cm}$, rotation time $1 \mathrm{~s}$, pitch factor 0.8 . We used an ultra-high resolution reconstruction kernel U75 u for image reconstruction. After denoising, we gained a $3 \mathrm{D}$ dataset with a nominal spatial resolution of $0.23 \mathrm{~mm} \times 0.23 \mathrm{~mm} \times 0.4 \mathrm{~mm}$.

To establish any dimensional changes produced by the pneumatic distension, we measured the changes in cross-sectional thickness of the walls at the left ventricular base and equator before and during pneumatic distension. We also measured the changes in length of the posterior, superior, septal and inferior walls. We then assessed the transverse transmural distribution of the aggregated units of cardiomyocytes in the superior, inferior, and posterior walls in the hearts prepared for computed tomographic analysis. To describe the visualized anatomic arrangements, we made multiplanar reconstructions of the superior, inferior and posterior walls with a slice thickness of $0.5 \mathrm{~mm}$ using OsiriX software (Pixmeo SARL, Bernex, Switzerland). This was achieved by aligning the selected mural segments along the long axis of the left ventricle, defined by the apex and the middle of the mitral valve, and along its short axis, 

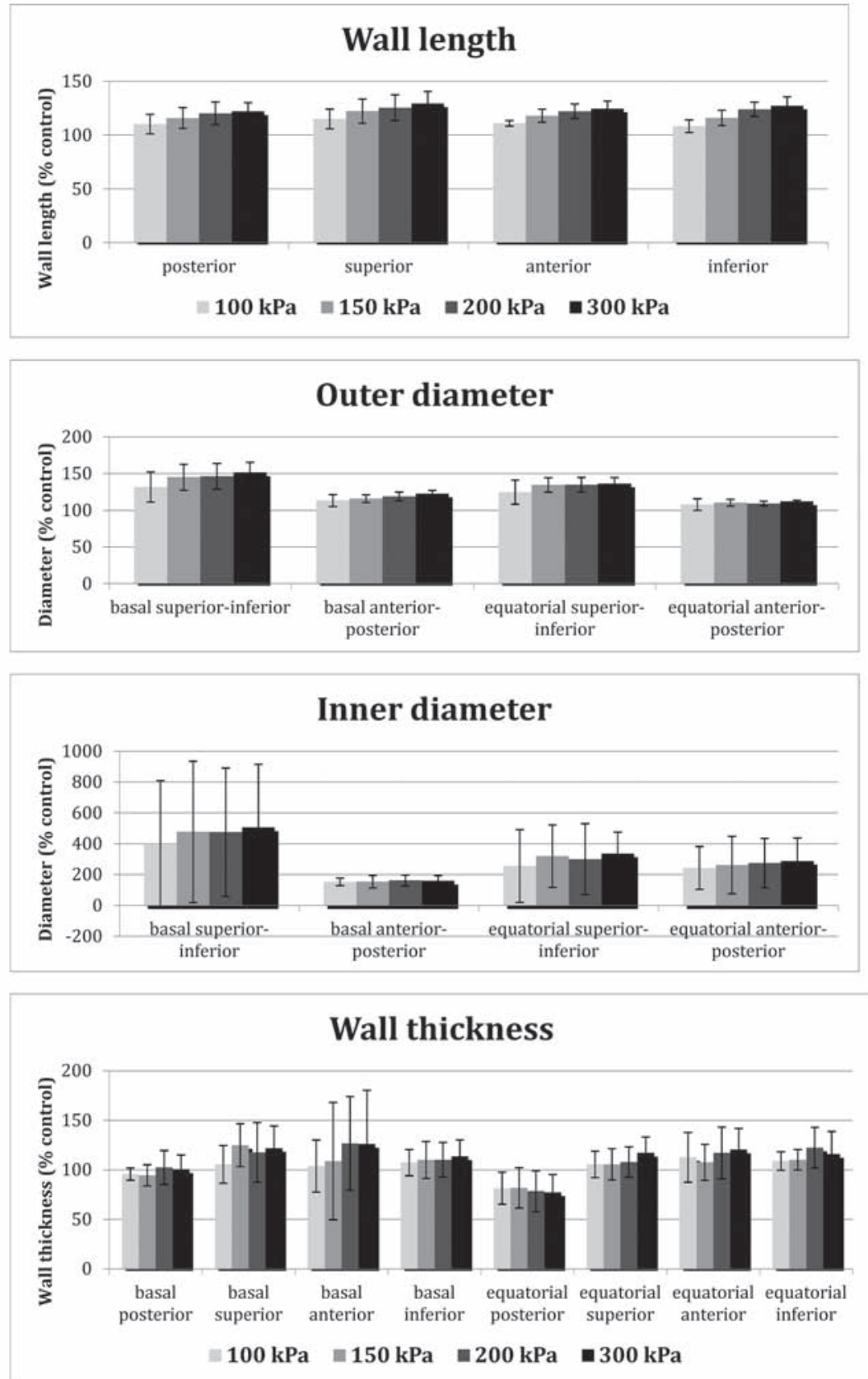

Fig. 1 The panels show the measured mean changes in ventricular dimensions of the 8 porcine hearts subjected to pneumatic distension followed by computed tomographic assessment. The rows show the changes for ventricular length and internal and external diameters of the ventricular cone as a proportion of the control measurements. The columns show the changes in the various quadrants of the ventricular walls with increasing pressure of distension shown in kilopascals (kp).

Abb. 1 Die Grafiken zeigen die mittleren Änderungen in den Kammerdimensionen der 8 Schweineherzen nach Blähung mit nachfolgender Computertomographie. Zunächst ist die Änderung der Kammerlänge, dann die Änderung des inneren und äußeren Durchmessers im Vergleich zur Ausgangsgröße dargestellt. Die Säulen stellen die Änderungen in den verschiedenen Quadranten der Wand bei wachsendem Blähdruck gemessen in kilopascal (kp) dar. which is defined by the tangential axis of the respective wall. While scrolling through the walls from the epicardium to the endocardium in the radial direction (마 Video 1), the local helical angles were measured in 20 equidistant steps through the regionally normalized depths ( $\bullet$ Fig. 2b). The points of measurement, therefore, refer to the relative thicknesses in the selected mural segments. Using an automatic, investigator-independent, computer-assisted technique depending on customized software based on algorithms described recently by Brune et al. [16], we measured the angulations of the chains of cardiomyocytes in one single heart, assessing the changes in terms of both the helical and transmural directions. In the 2 hearts prepared for histological validation, we rinsed the coronary arteries with saline, inflated them for several minutes with compressed air, and perfused them with $4 \%$ formaldehyde for 2 days, using a pressure of perfusion comparable to distension at 300 kilopascals. We then sampled the walls at the regional sites identified for the purpose of echocardiographic analysis [17]. We sectioned the blocks taken from the first heart in the short axis ( $\bullet$ Fig. 4, 6), with those from the second heart cut parallel to the ventricular long axis ( $\bullet$ Fig. 5), ensuring that all sections extended in a fully transmural fashion. The sections were stained with Azan, rendering the cardiomyocytes red, and the supporting connective tissue blue.

\section{Results \\ V}

Irrespective of arrest in systole or diastole, the ventricular length increased with pressure, albeit variably at the different sites of measurement ( $\bullet$ Fig. 1). The changes in mural thickness were si- 


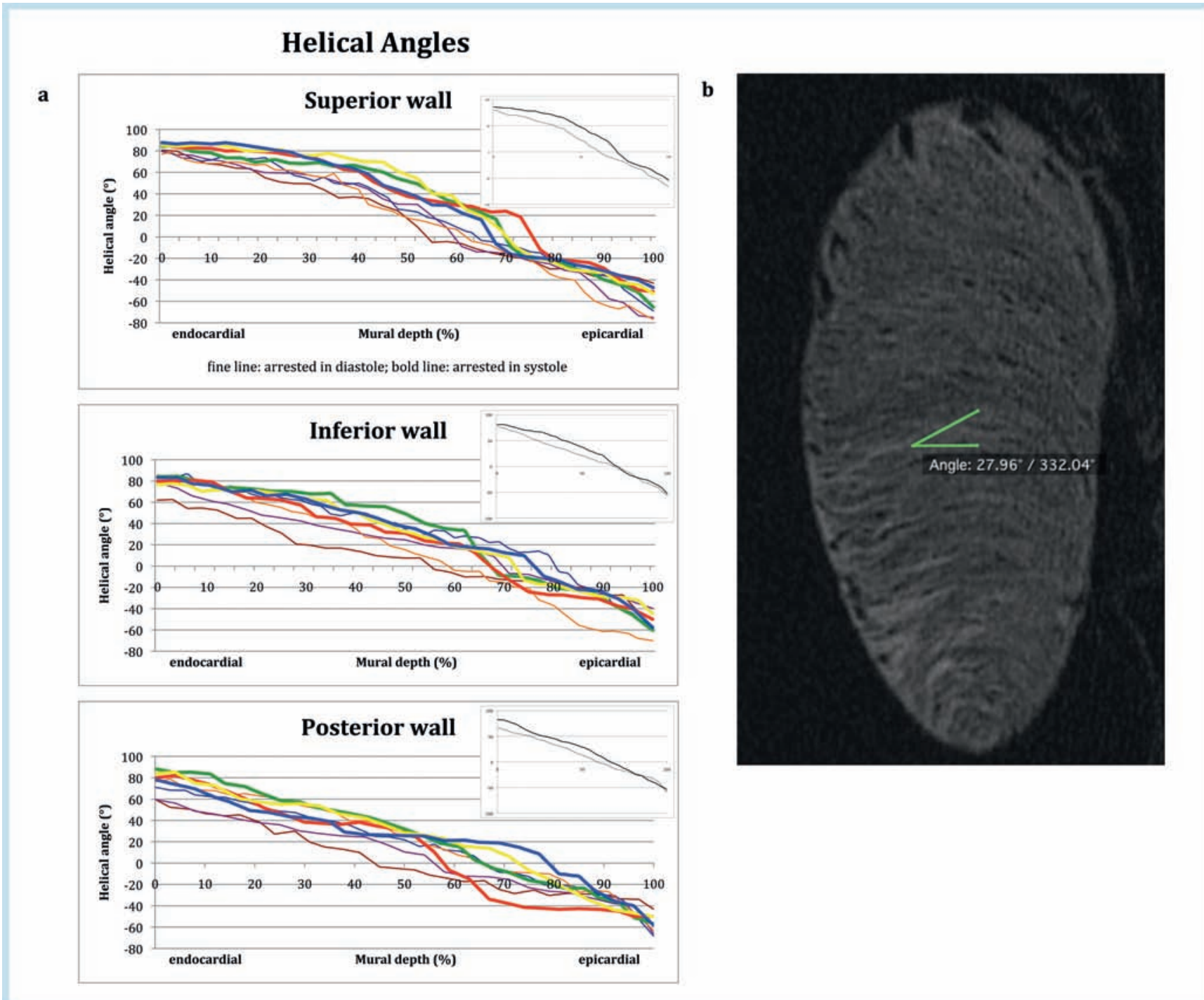

Fig. 2 a The panels show the measurement of the transmural change in helical angulation of the chains of aggregated cardiomyocytes in the hearts arrested in diastole (fine lines) compared to those arrested in systole (bold lines). The measurements were made in segments from the superior (upper), inferior (middle) and posterior (lower) quadrants of the ventricular cone. The differences did not reach statistical significance in any segment, although there is a trend to higher mean helical angles in the inner two thirds of the walls of hearts arrested in systole, as shown in the insets. b Measurement of a helical angle of $28^{\circ}$ in a dataset aligned perpendicular through the posterior wall.
Abb. 2 a Die Grafik zeigt die transmurale Drehung der Helix-Winkel von Aggregaten langer Myozyten-Ketten in Herzen, die einerseits in Diastole (feine Linien) oder in Systole (dicke Linien) stillgestellt wurden und dies in der superioren (oben), inferioren (mitte) und posterioren (unten) Wand der linken Kammer. In keiner Position wurde statistische Signifikanz erreicht. In systolisch stillgelegten Herzen zeigt sich ein Trend zu höheren mittleren Winkeländerungen (Einschub). b Messung eines Helixwinkels von $28^{\circ}$ in einem Datensatz, der rechtwinklig durch die posteriore Wand ausgerichtet ist.

duced by the aggregation of the individual cardiomyocytes also varied markedly within the different ventricular regions. When seeking to provide a meaningful account for our observations, we therefore considered that assessment of the findings as seen in the short axis of the ventricular cone permitted recognition of endocardial and epicardial layers of aggregated cardiomyocytes, along with a central zone, in which the individual cardiomyocytes were aggregated together in circumferential fashion. Units of aggregated cardiomyocytes could then be seen transitioning between the central and peripheral layers. This produced an obvious feathered appearance within individual short-axis sections, with the central layer of aggregated cardiomyocytes forming the spine of the observed feather. When the findings were assessed in the long axis of the ventricular cones, however, the aggregated cardiomyocytes were seen to be inter-related in a 

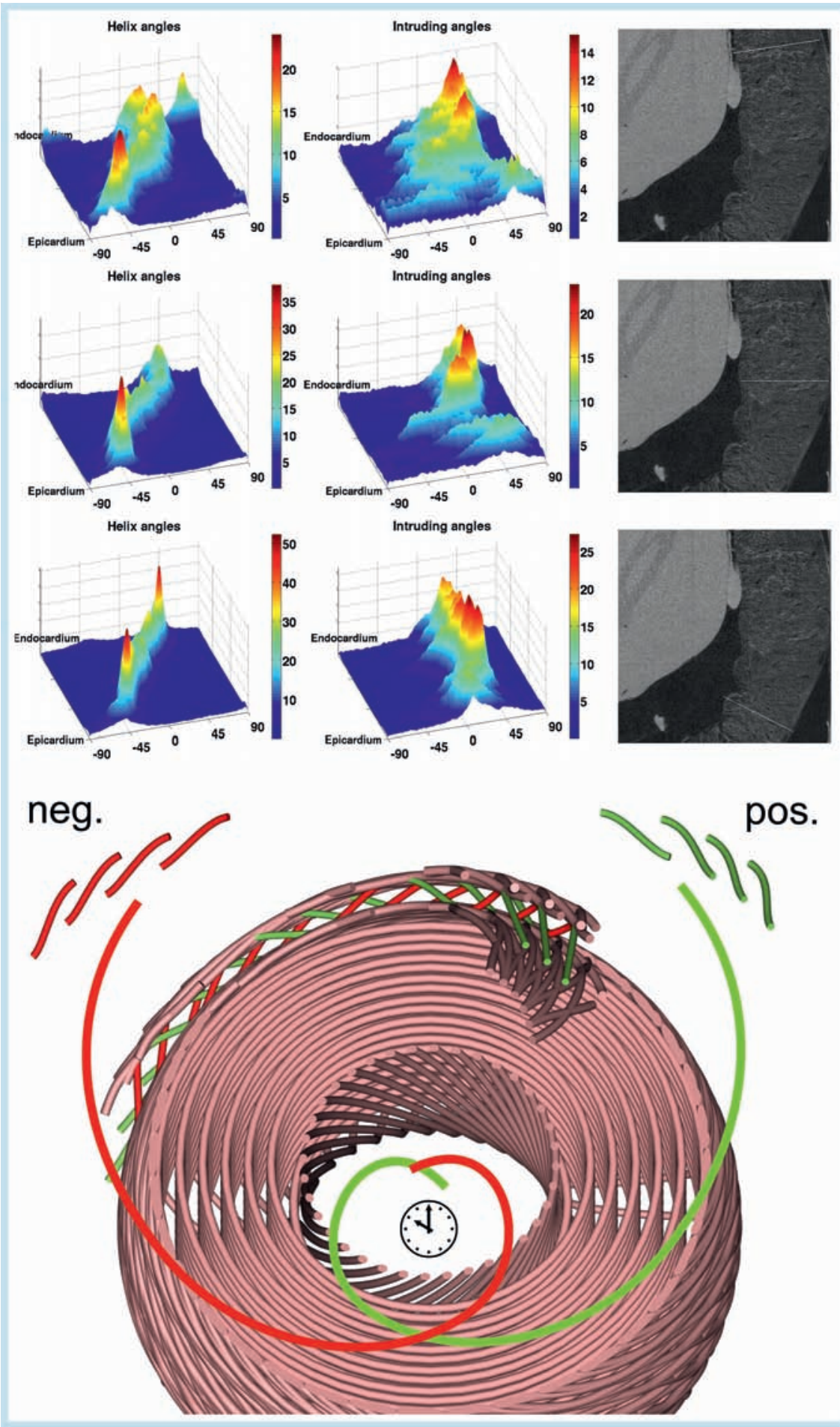

Fig. 3 The upper three rows of the figures show the distribution of helical angles (left hand panels) and transversely intruding angles (middle panels) as assessed using the computed tomographic images from the basal, middle, and apical thirds of the ventricular cone as measured using the computerderived system [16]. The right-hand panels show the location of the site of measurement relative to the long axis of the posterior ventricular wall (right panel). On the $x$-axes of the plots, we have shown the angles between plus and minus 90 degrees of the chains of aggregated cardiomyocytes. The $y$ axes show the mural depth between the epicardium and endocardium as a proportion of the mural thickness. On the z-axes, we show the density of aggregated cardiomyocytes with comparable angulations. The lower panel depicts in cartoon fashion our interpretation of the three-dimensional aggregation of the chains of cardiomyocytes, with negative intruding chains shown in red and positive intruding chains shown in green. A positive sign is denoting an epi- to endocardial spiral in clockwise direction seen from the apex, while a negative sign denotes a counterclockwise spiral from the epicardium to the endocardium. Tangentially aligned chains of cardiomyocyes are shown in pink.

Abb.3 Die oberen drei Reihen der Grafik zeigen die Verteilung der Helix-Winkel (links) und der queren Eindring-Winkel (mittlere Spalte) abgeleitet aus den computertomographischen Bildern nach Blähen der Herzen und unter Verwendung eines computerassistierten automatischen Auswertverfahrens. Die rechten Graphiken zeigen die Messorte in der freien Wand der linken Kammer. Auf der $x$-Achse sind die Winkel zwischen plus und minus 90 Grad aufgetragen, die y-Achse zeigt die Wandtiefe des Messortes in \% der Wanddicke, die z-Achse zeigt die Dichte der Messwerte am Messort an. Die untere Darstellung zeigt im Model grob vereinfacht die Anordnung von langen Myozytenketten mit der Angabe der positiven (grün) oder negativen (rot) Eindringrichtung der Vernetzung in die Wandtiefe - von der Kammerspitze aus betrachtet -, wobei das positive Vorzeichen einen Schrägverlauf im Uhrzeigersinn, das negative einen solchen im Gegenuhrzeigersinn anzeigen. complex three-dimensional fashion. Scrolling through the overall sequence of cross-sectioned slices from base to apex and from apex to base ( Video 2 ), revealed a virtual rotation of the inner and outer fans of the feather, with the spine of the feather seeming to remain motionless. The direction of rotation was reversed when traced from base to apex, as opposed to apex to base. Comparable scrolling through the long axis series ( 0 Fig. 6, lower panel and Video 3) again showed the cardiomyocytes to be aggregated into units with complex relationship to each other. Those originating in the lower half of the left ventricle ascended towards the ventricular base, seemingly also moving from epicar- dial to endocardial locations within the thicknesses of the ventricular walls. The spaces between the aggregated units, however, as assessed anatomically were less obvious in the upper half of the septum. The observations described above take account of our interpretations as based on gross anatomical observation and were comparable in all distended hearts. To provide some quantification of the anatomic observations, we used computer-assisted rendering to qualitatively assess the angulation of the chains of aggregated cardiomyocytes in helical and transmural directions. This analysis revealed marked variations between the basal, middle, and apical thirds of the ventricular cone ( $\bullet$ Fig. $\mathbf{3}$ ). 

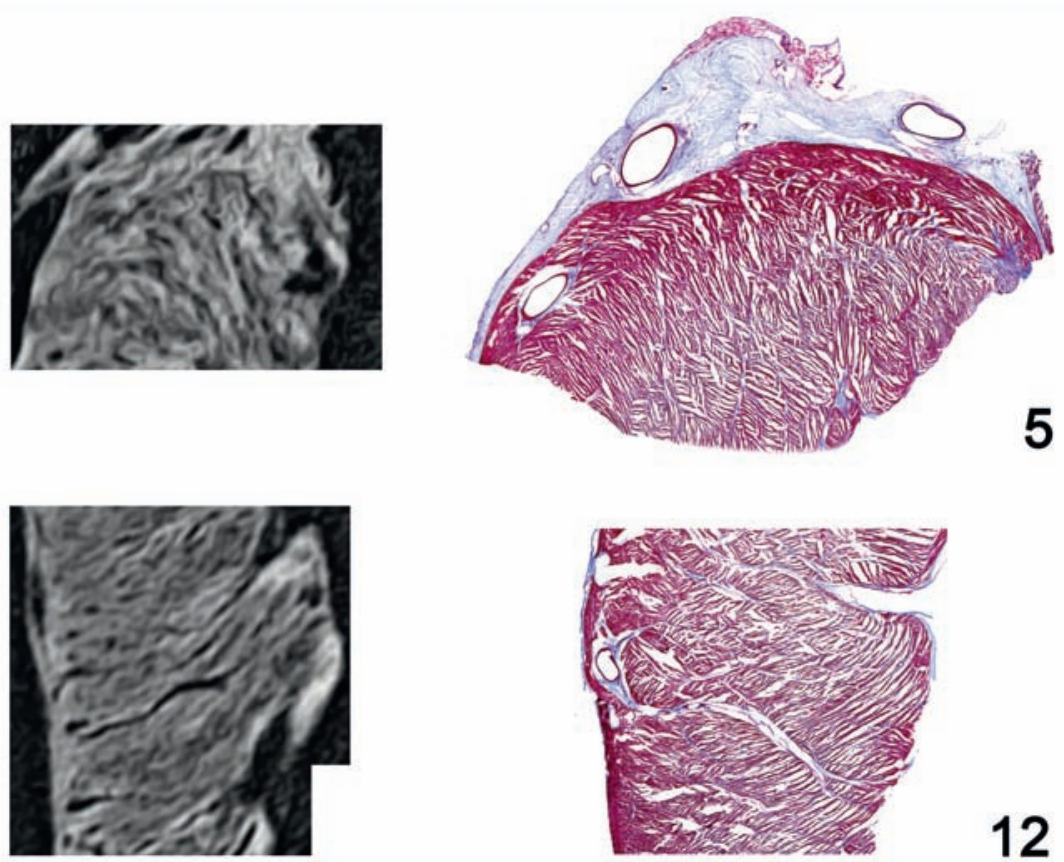

Fig. 4 The images show longitudinal sections through the walls of the ventricular mass as obtained from ventricular segments 5 (upper panels) and 12 (lower panels), comparing the findings obtained using computed tomography (left-hand panels) and histology (right-hand panels). The areas shown by computed tomography and histology are not identical, although taken from the same ventricular segments hence single sheet-like formations in the one image cannot be identified in the other. Nonetheless, the main striation prevailing in each segment is documented in both images. Note that, although many components of myocardium are aggregated in sheet-like formation, none of the sheets extend in a fully transmural fashion. Note also the marked difference in architecture between the patterns of the aggregates in the basal (upper) and middle (lower) thirds of the ventricular cone.

Abb. 4 Die Darstellung zeigt histologische Längsschnitte (links) durch die linke Kammerwand in den Segmenten 5 (oben) und 12 (unten) und die entsprechenden Segmente im CT (rechts). Der Herzmuskel ist zu Lamellen aufgefächert. Kein Fächer durchbricht die gesamte Wanddicke. Beachte die hohe strukturelle Variabilität innerhalb der Kammerwand.

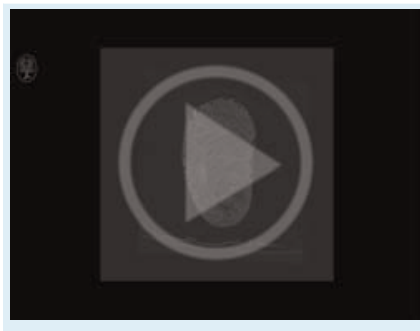

먼 Video 1: The stack of computed tomographic tangential sections is scanned through the posterior wall of the left ventricle from the epicardium to the endocardium.

Video 1: Sequenz von CT-Bildern der posterioren linken Kammerwand in transmuraler Richtung vom Epikard zum Endokard.

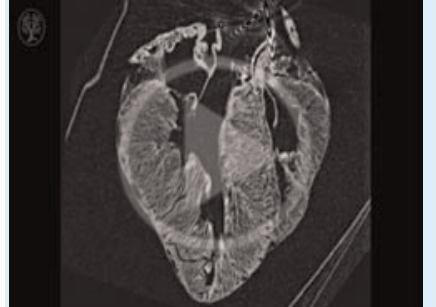

마 Video 3: The stack of computed tomogaphic images is scanned in long axial fashion.

Video 3: Sequenz von CT-Bildern im Längsschnitt des Herzens unter Drehung um eine Achse im Zentrum des linken

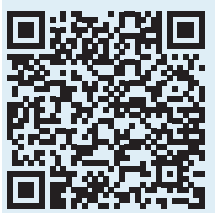
Kammerlumens.
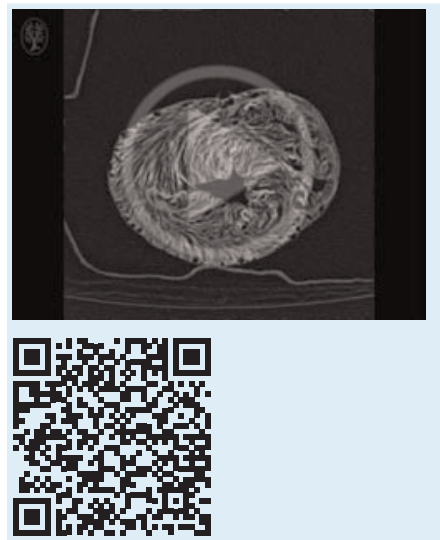

Video 2: The stack of computed tomographic images as obtained in cross-section of the ventricular cone are scanned from apex to base.

Video 2: Sequenz von CTBildern von Querschnitten durch das Herz in apiko-basaler Abfolge.

An obvious S-like distribution of the helical angles was seen in the basal region of the cone (upper left panel of $\bullet$ Fig. 3), but was less obvious in the middle third of the cone, and absent from the apical third. Analysis of the intruding or extruding transmural populations revealed a low distribution in the outer half of the wall in the basal and middle thirds of the ventricular cone, with intrusion being greatest in the lower third.

\section{Histological findings}

Analysis of the sections taken in both short and long axis planes confirmed our gross anatomical evaluations of the computed tomographic images. The histological sections showed that the individual cardiomyocytes were aggregated together into units separated by spaces, presumably induced by the pneumatic distension $(\bullet$ Fig. 4). However, the units of aggregated cardiomyocytes separated by the spaces showed marked variation in both their shape and orientation within the different ventricular regions. As assessed in the short axis ( $\bullet$ Fig. 4 ), a layer of cardiomyocytes aggregated in circumferential fashion was seen in all regions. In a gross assessment, the extent of this central layer was seen to vary markedly, not only in terms of thickness but also with respect to its depth between the epicardium and the endocardium. Examination of the segments taken from the middle third of the ventricular cone confirmed the feathered appearance as revealed by the tomo- 


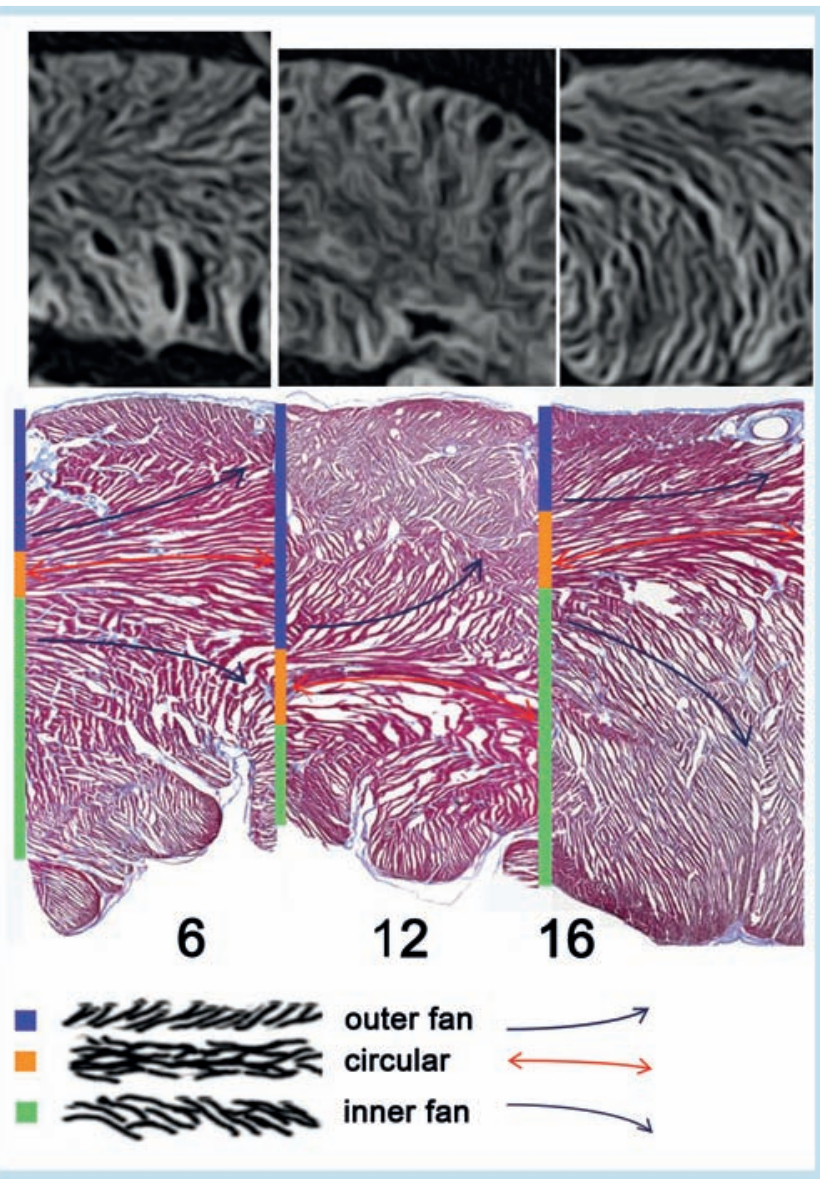

Fig. 5 The images show the comparisons between the findings revealed by computed tomography (upper panels) and histology (lower panels) following analysis of short axis sections of the ventricular walls obtained from segments 6 (left hand panels), 12 (middle panels) and 16 (right hand panels). The colouring to the left hand side of the histological sections show the compartments of the wall deemed to be formed by the aggregated cardiomyocytes. The blue layer showing the transitional blocks extending from epicardium towards the middle layer, shown in orange. The green layer then depicts the transition towards the endocardial blocks. The drawings at the bottom of the figure show the alignment of the chains of cardiomyocytes within the designated layers. Note the markedly variable thickness of the different layers, and the variation of the depth of the circular aggregates relative to the thickness of the ventricular walls. Note also the lack of any fully transmural aggregates.

Abb. 5 Gegenüberstellung histologischer Querschnitte durch die Segmente 6, 12 und 16 und ihrer Darstellung im CT: Die Farbmarkierung begrenzt Kompartimente in der Wand in ein subepikardiales äußeres Fan (blau), eine Mittellage (orange) und ein inneres subendokardiales Fan (grün). Darunter ist die typische Lamellenanordnung in den drei Kompartimenten skizziert. Beachte, dass die Kompartimente in den drei Wandsegmenten deutlich unterschiedlich dick sind und dass insbesondere die Mittellage unterschiedlich tief in der Wand liegt. Auch hier sind keine Lamellen erkennbar, die die gesamte Wanddicke durchbrechen.

graphic analysis, with aggregated units of the myocardium extending away from the circumferential cardiomyocytes towards the endocardial and epicardial layers. Densely aggregated layers of cardiomyocytes were seen in some, but not all, of the subendocardial parts of the wall in the different ventricular regions, with similar variation noted in the pattern of the sub-epicardial layers. Throughout the segments it nonetheless proved possible to recognize an overall mural architecture based on division of the wall into central, endocardial, and epicardial components, with transi-

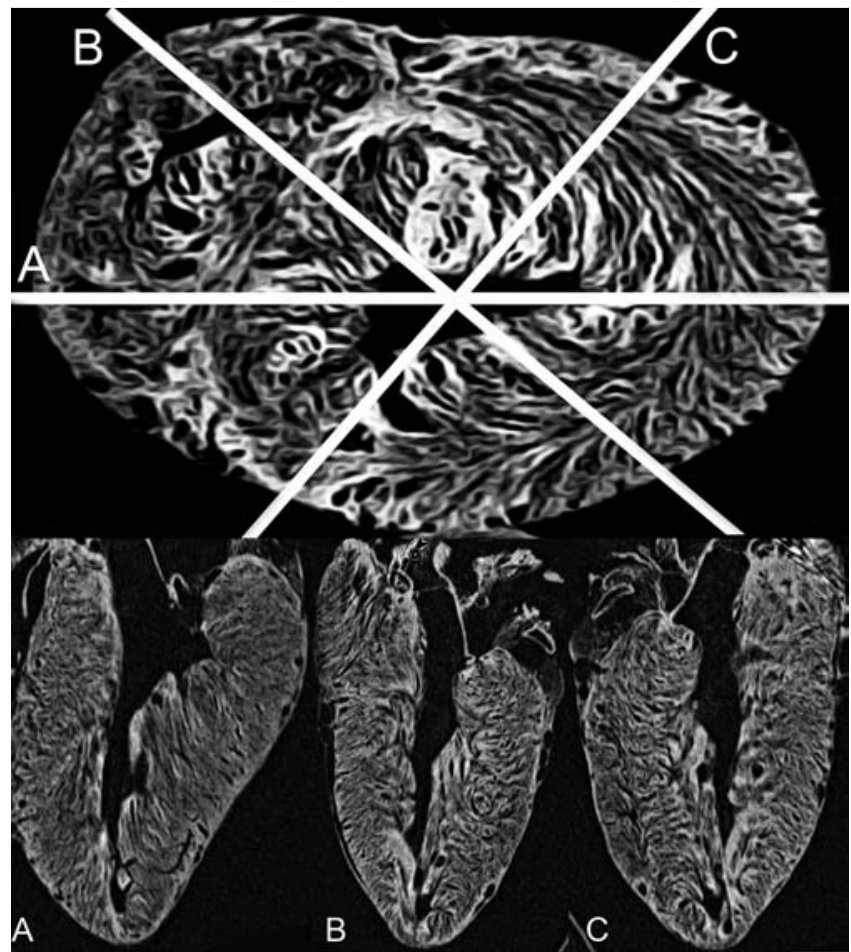

Fig. 6 The upper panel of the figure shows a cross-section through the middle third of the ventricular cone as obtained using computed tomographic visualization of the distended ventricular mass. The three lower panels show the corresponding long axial images along planes A-C through the cross-sectional image. Note the marked discrepancy between the patterns of the blocks of the myocardium as seen on the short axial and long axial images. To date, it has not proved possible to assess the full extent of an individual block of the myocardium.

Abb. 6 Das obere Bild zeigt einen Querschnitt durch das Herz in der mittleren Äquatorialzone im CT-Bild nach pneumatischer Entfaltung des Myokards. Die drei unteren Bilder zeigen Längsschnitte durch dasselbe Herz in den Positionen A, B, und C. Beide Darstellungen lassen die hohe regionale Variabilität der Struktur erkennen. Bisher ist eine Darstellung von Lamellen in ihrer ganzen Ausdehnung nicht gelungen.

tional zones then extending between the central and border zones. Although the cardiomyocytes aggregated together to form, these units were separated from one another by spaces, with additional spaces within each layer as defined for the purpose of description. There were no discrete anatomical boundaries between any of the observed components. The five-layered appearance observed in the middle third of the ventricular cone, however, was lacking at the apex, where thick strands of parallel units spiraled in a centripetal direction. The five-layered arrangement was similarly lacking at the ventricular base, where the spaces between the aggregated cardiomyocytes were aligned more or less at right angles to one another. In the middle third of the ventricular cone, when assessed in the long axis, the spaces between the units of the myocardium extended across the wall in an almost radial fashion. These series of spaces between units of the myocardium descended towards the apex in the subepicardial third of the walls, but ascended towards the base in the subendocardial third, with the lengths of the spaces between the units, as assessed in terms of gross anatomy, varying markedly within the different ventricular regions. 


\section{Discussion}

$\nabla$

By using passive pneumatic distension of the ventricular cone, injecting compressed air through the coronary arteries, we succeeded in exaggerating the mural architecture produced by the binding together of chains of cardiomyocytes within the endomysial components of the fibrous matrix to produce aggregated units [14]. We have described these units simply as "aggregated cardiomyocytes", since we found no structures that could be interpreted as representing discrete anatomical "fascicles" or "fibers". Our interpretation of our current findings regarding the gross anatomical arrangement of these aggregated units nonetheless differ from presumptions made previously by some investigators subsequent to analysis of ventricular mural architecture using diffusion tensor magnetic resonance imaging [3-5]. We should emphasize, however, that our own findings are not necessarily incompatible with the findings produced by diffusion tensor imaging. The angulations of the tracts revealed by such analysis reflect the alignment of the long chains of aggregated cardiomyocytes. It is presumed, however, that the secondary or the tertiary eigenvector of the diffusion tensor then provides a surrogate of the alignment of the sheets into which the cardiomyocytes themselves are believed to be aggregated. Although it is now possible to obtain high resolution when using diffusion tensor imaging, the resolution available to earlier investigators [3-5] was insufficient to make such conclusions regarding the extent of the "sheets" inferred to be present on the basis of the measurement of the primary and tertiary eigenvectors. Our own analysis confirms that there is an obvious organization of cardiomyocytes to produce aggregated units within the ventricular walls. The specific mural architecture, however, varies markedly within the different ventricular regions now recognized echocardiographically [17]. The arrangement of the units into which the cardiomyocytes are aggregated, the spaces between the units being accentuated by the pneumatic distension, is then seen to vary markedly when assessed in the short axis as opposed to the long axis of the ventricular cone. Even within our images, as produced by computed tomography, it is still not possible to recognize individual cardiomyocytes or to assess the full extent of the units into which the cardiomyocytes are aggregated. Therefore, we do not consider it justified to maintain that the alignment of the presumed sheets into which the cardiomyocytes are aggregated is normal to the alignment of the long chains of cardiomyocytes within them as has been the case to date. Our overall findings, as interpreted on the basis of the three-dimensional gross anatomic analysis permitted by the computed tomographic reconstruction, must call into question the generally accepted notion that the sheets of cardiomyocytes extend in a fully transmural fashion, and that, in terms of thickness, they are composed of four to six cardiomyocytes [7].

Our images, in fact, support the descriptions provided quite some time ago by Feneis [8] and Hort [9]. They also endorse the observation made over a century ago, namely that at various depths within the central component of the ventricular wall, when assessed in the short axis, the cardiomyocytes positioned centrally within the thickness of the ventricular walls are aligned in a circumferential fashion. These are the cardiomyocytes believed by Krehl [18] to provide the driving force for ventricular emptying. Perhaps more importantly, the quantitative, as opposed to qualitative, observations we were able to make using an automated system that avoids the need for subjective interpretation [16] confirm that a significant proportion of cardiomyocytes are aligned in a transmural fashion across the ventricular walls [11]. These measurements provided no support for the notion that all cardiomyocytes are aligned in a virtually tangential fashion. It is the latter dogma, put forward initially by Frank [10], that has prevailed to date, with support for this notion provided by the histological measurements made by Streeter and colleagues [6].

From a mechanistic point of view, the myocardium represents a highly structured continuum. Our current observations show that a notable characteristic of this continuum is the marked heterogeneity of the mural architecture in the different ventricular regions. In particular, our qualitative observations, supported by our quantitative measurements, reveal a variable mixture of populations of cardiomyocytes aligned in surface-parallel or transmural directions. It is the presence of the spaces between the aggregated cardiomyocytes occupied by loose perimysial tissue that permits their gliding relative to one another during systolic ventricular contraction, thus explaining the paradox of systolic mural thickening [19]. The dense packing of the cardiomyocytes produced by the endomysial component of the fibrous matrix, however, limits the diastolic extension of the myocardium, yet transmits forces and stores energy during systole [19]. When considered on the basis of continuum mechanics, because of the numerous branchings between the individual cardiomyocytes, the principal stresses occurring during systolic contraction do not coincide with the striation of the myocytes. It is the linkage within the fibrous matrix that permits action as a power train. Taken together, the slippage between the myocardial units accounts for the large changes in shape and dimension of the ventricular mass over the cardiac cycle, underscoring the major transmural gradients of three-dimensional strain, with predominant dimensional changes observed in the inner wall [19].

The marked heterogeneity in the extent of aggregation of the individual cardiomyocytes, furthermore, indicates a local "fingerprint" for each ventricular region, these regions representing the "segments" as identified echocardiographically [17], thus pointing to the well-recognized regional variability in antagonistic function of the wall $[11,12,20-22]$. The simultaneous coexistence of dilating and constrictive activity in the ventricular myocardium was measured previously, a feature which prevails throughout the cardiac cycle [11]. We suggest that this mechanism, which was described as antagonism, is designed to control the mean ventricular shape and size. It also controls the speed and amount of regional systolic inward motion, hence molding intra-cavitary flow, and accounting for the known spiraling shape and speed of flow through the aortic outflow tract [23]. By intermittently storing elastic forces, the antagonistic mechanism operates the early diastolic outward motion, and hence the shape and velocity of early diastolic inflow [24]. We should emphasize that our focus on regionally confined mural dynamics contrasts with the notion of a band-like myocardial continuum, as was postulated initially by Torrent-Guasp [25]. This latter concept, while still accepted by some [26], is incompatible with the demonstrated anatomic arrangement of the individual cardiomyocytes being aggregated together into a three-dimensional array of units separated by spaces occupied by loose perimysial tissues. Our account of continuum mechanics serves to correlate local with global ventricular dynamics in the normal heart, but particularly in the setting of heart failure. Global function is the joint effect of the highly variable patterns of local wall motion, which also means that an almost deliberate pattern of even partially disturbed local functions may fail to disrupt global function [27]. An essential component of this global function is the antagonism provided between the tangential and intruding populations of cardiomyocytes, thus underscoring the co-existence of unloading and auxotonic systolic forces $[11,28]$. It is axiomatic that knowledge of ventricular mural architecture is essential when assessing the clinical findings now 
revealed using computed tomography or magnetic resonance imaging [2]. Our current findings should also provide the means of interpreting new imaging modalities currently in development, such as the integration of positron emission tomography and magnetic resonance imaging [29]. It is our hope that they will provide a deeper understanding of the processes underscoring the different disease entities.

We nonetheless recognize the obvious limitation of our study, i. e., that we investigated pig hearts, not human hearts. However, our current study is methodological and should serve to optimize the details of processing before making it potentially applicable to autopsied human hearts.

\section{Clinical Relevance}

Pneumographic distension of the autopsied heart, coupled with computed imaging, reveals the structure of the myocardium of the whole heart within minutes.

The myocardium is a highly structured continuum with local segmental differentiation.

The ventricular walls are arranged neither in the form of transmural sheets, nor a unique band, but rather in the form of blocks of aggregated cardiomyocytes separated by planes of cleavage.

\author{
Affiliations \\ Department of Clinical Radiology, University Hospital Münster, Germany \\ 2 Dept. of Experimental Thoraco-vascular Surgery, University Hospital \\ Münster, Germany \\ ${ }^{3}$ Institute for Biomedical Engineering, ETH and University of Zürich, \\ Switzerland \\ ${ }^{4}$ Department of Applied Mathematics, University of Twente, Netherlands \\ ${ }^{5}$ Center for Reproductive Medicine and Andrology, University Hospital \\ Münster, Germany \\ ${ }^{6}$ Dept of Cardiothoracic and Vascular Surgery, Skejby Sygehus, Aarhus \\ University Hospital, Aarhus, Denmark \\ 7 Dept. Surgical Research, Clinic of General and Visceral Surgery, University \\ Hospital Münster, Germany \\ 8 Department of Radiology, University of Cologne, Germany \\ 9 Institute of Genetic Medicine, Newcastle University, London, United \\ Kingdom of Great Britain and Northern Ireland
}

\section{Acknowledgment}

Supported by grants of: Deutsche Forschungsgemeinschaft (DFG), Karl- and Lore-Klein Foundation, German Heart Foundation, BMBF Germany. We thank Peter Agger for preparing the work for submission. We thank Marcus Hempel for assistance concerning the figures.

\section{References}

1 Lower $R$. (ed) Tractatus de corde item de motu \& colore sanguinis et chyli in eum transitu. Amstelodami: Elzevir; 1669

2 Achenbach S, Barkhausen J, Beer $M$ et al. Consensus recommendations of the german radiology society (DRG), the german cardiac society (DGK) and the german society for pediatric cardiology (DGPK) on the use of cardiac imaging with computed tomography and magnetic resonance imaging. Fortschr Röntgenstr 2012; DOI: 10.1055/s-00311299400

3 Helm P, Beg MF, Miller MI et al. Measuring and mapping cardiac fiber and laminar architecture using diffusion tensor MR imaging. Ann N Y Acad Sci 2005; DOI: 1047/1/296 [pii]

4 Chen J, Liu W, Zhang $\mathrm{H}$ et al. Regional ventricular wall thickening reflects changes in cardiac fiber and sheet structure during contraction:
Quantification with diffusion tensor MRI. Am J Physiol Heart Circ Physiol 2005; DOI: 289/5/H1898 [pii]

5 Dou J, Tseng WY, Reese TG et al. Combined diffusion and strain MRI reveals structure and function of human myocardial laminar sheets in vivo. Magn Reson Med 2003; DOI: 10.1002/mrm.10482 [doi]

6 Streeter D, Bassett D. An engineering analysis of myocardial fiber orientation in pig's left ventricle in systole. Anat Rec 1966; 155: 503-511

7 LeGrice IJ, Takayama Y, Covell JW. Transverse shear along myocardial cleavage planes provides a mechanism for normal systolic wall thickening. Circ Res 1995; 77: 182-193

8 Feneis H. Das Gefüge des Herzmuskels bei Systole und Diastole. Gegenbauers Morphologisches Jahrbuch 1944/45. 89: 406-471

9 Hort $W$. Macroscopic and micrometric research on the myocardium of the left ventricle filled to varying degrees. Virchows Arch Pathol Anat Physiol Klin Med 1960; 333: 523-564

10 Frank O. Isometrie und Isotonie des Herzmuskels. Z Biol 1901; 41: 14-34

11 Lunkenheimer PP, Redmann $K$, FlorekJ et al. The forces generated within the musculature of the left ventricular wall. Heart 2004; 90: 200-207

12 Lunkenheimer PP, Redmann K, Kling $N$ et al. Three-dimensional architecture of the left ventricular myocardium. Anat Rec A Discov Mol Cell Evol Biol 2006; DOI: 10.1002/ar.a.20326 [doi]

13 Anderson RH, Ho SY, Sanchez-Quintana D et al. Heuristic problems in defining the three-dimensional arrangement of the ventricular myocytes. Anat Rec A Discov Mol Cell Evol Biol 2006; DOI: 10.1002/ar. a.20330 [doi]

14 Caulfield JB, Borg TK. The collagen network of the heart. Lab Invest 1979; 40: 364-372

15 Lunkenheimer PP, Muller RP, Konermann $C$ et al. Architecture of the myocardium in computed tomography. Invest Radiol 1984; 19: 273-278

16 Brune C, Sawatzky A, Burger M. Primal and dual bregman methods with application to optical nanoscopy. Int J Comput Vis 2011; 92: 211-229

17 Edwards WD, Tajik AJ, Seward JB. Standardized nomenclature and anatomic basis for regional tomographic analysis of the heart. Mayo Clin Proc 1981; 56: 479-497

18 Krehl L. Beiträge zur Kenntnis der Füllung und Entleerung des Herzens. Abhandlungen der math-physischen Classe d Königl Sächs Ges Wiss 1891; 17: $341-383$

19 Spotnitz HM, Spotnitz WD, Cottrell TS et al. Cellular basis for volume related wall thickness changes in the rat left ventricle. J Mol Cell Cardiol 1974; DOI: 0022-2828(74)90074-1 [pii]

20 Lunkenheimer PP, Niederer P. Hierarchy and inhomogeneity in the systematic structure of the mammalian myocardium: Towards a comprehensive view of cardiodynamics. Technol Health Care 2012; DOI: 10.3233/THC-2012-0690 [doi]

21 Henk E, ter KeursJ, Waldmann L et al. Wall thickening, shears, and cleavage planes. In: Ingels J, Daughters G, Baan J, Covell J, Renemann R, Yin F (eds) Systolic and diastolic Function of the Heart. IOS Press and Ohmsha; 1995: 345-362

22 Schmid P, Lunkenheimer PP, Redmann K et al. Statistical analysis of the angle of intrusion of porcine ventricular myocytes from epicardium to endocardium using diffusion tensor magnetic resonance imaging. Anat Rec (Hoboken) 2007; DOI: 10.1002/ar.20604 [doi]

23 Machler $H$, Reiter $G$, Perthel $M$ et al. Influence of a tilting prosthetic mitral valve orientation on the left ventricular flow - an experimental in vivo magnetic resonance imaging study. Eur J Cardiothorac Surg 2007; DOI: S1010-7940(07)00267-9 [pii]

24 Bettendorff-Bakman DE, Schmid P, Lunkenheimer PP et al. Diastolic ventricular aspiration: A mechanism supporting the rapid filling phase of the human ventricles. J Theor Biol 2008; DOI: S0022-5193(07)00539-5 [pii]

25 Torrent-Guasp F, Kocica MJ, Corno AF et al. Towards new understanding of the heart structure and function. Eur J Cardiothorac Surg 2005; DOI: S1010-7940(04)00913-3 [pii]

26 Buckberg GD, Hoffman JI, Coghlan HC et al. Ventricular structure-function relations in health and disease: Part I. the normal heart. Eur J Cardiothorac Surg 2015; DOI: 10.1093/ejcts/ezu278 [doi]

27 Dorri F, Niederer PF, Redmann K et al. An analysis of the spatial arrangement of the myocardial aggregates making up the wall of the left ventricle. Eur J Cardiothorac Surg 2007; DOI: S1010-7940(06)01087-6 [pii]

28 Schmitt B, Li T, Kutty S et al. Effects of incremental beta blocker dosing on myocardial mechanics of the human left ventricle: MRI 3D-tagging insight into pharmacodynamics. Am J Physiol Heart Circ Physiol 2015; DOI: 10.1152/ajpheart.00746.2014 [doi]

29 Nensa F, Schlosser T. Cardiovascular hybrid imaging using PET/MRI. Fortschr Röntgenstr 2014; DOI: 10.1055/s-0034-1385009 [doi] 